\title{
Short-term responses of selected soil properties to clearing and cropping of miombo woodlands in central Zimbabwe
}

\author{
F. Mapanda ${ }^{\mathrm{a}, *}$, S. Munotengwa ${ }^{\mathrm{a}}$, M. Wuta ${ }^{\mathrm{a}}$, P. Nyamugafata ${ }^{\mathrm{a}}$, J. Nyamangara ${ }^{\mathrm{b}}$ \\ a Department of Soil Science and Agricultural Engineering, University of Zimbabwe, P.O. Box MP167, Mt. Pleasant, Harare, Zimbabwe \\ ${ }^{\mathrm{b}}$ International Crops Research Institute for the Semi-Arid Tropics, Matopos Research Station, P.O. Box 776, Bulawayo, Zimbabwe
}

A R T I C L E I N F O

\section{Article history:}

Received 6 September 2012

Received in revised form 21 January 2013

Accepted 22 January 2013

\section{Keywords:}

Aggregate stability

Cleared woodland

Microbial biomass

Miombo

Tillage

\begin{abstract}
A B S T R A C T
Clearing and cultivation of indigenous woodlands for agriculture may be among the most important mechanisms of physical, chemical and biological land degradation in Zimbabwe, and southern Africa in general. The objective of the study was to determine the effects of clearing miombo woodland and converting the land to maize (Zea mays L.) cropping on selected soil properties on clay (Chromic luvisol) and loamy sand (Ferric acrisol) soils in central Zimbabwe. Soil samples were collected from undisturbed, cleared and cultivated woodlands after four cropping seasons and analyzed for soil organic $\mathrm{C}$, total $\mathrm{N}$ and $P$, exchangeable bases, cation exchange capacity, infiltration rate, aggregate stability and microbial biomass $\mathrm{C}$ and $\mathrm{N}$ at $0-5,6-10$ and $11-20 \mathrm{~cm}$ depths. Results showed that clearing and conversion of miombo woodlands to croplands reduced soil nutrients, cation exchange capacity (range: 9.6$21.0 \mathrm{cmol}_{\mathrm{C}} \mathrm{kg}^{-1}$ in clay; $7.0-15.5 \mathrm{cmol}_{\mathrm{c}} \mathrm{kg}^{-1}$ in loamy sand), and microbial C (range: $0.06-0.54 \%$ in clay; $0.02-0.37 \%$ in loamy sand). The extent and nature of change was variable, depending on the soil type and depth. Clearing of trees and leaving soil surface covered with grass did not always translate to a significant decline in soil organic C after four seasons (range: $0.69-2.24 \%$ in clay; $0.24-1.43 \%$ in loamy sand), unless the clearing was followed by successive cultivation and cropping without $\mathrm{N}$ fertilization. The reduced soil quality under cultivation was attributed to a potential pulse in decomposition and mineralization processes caused by soil disturbance, followed by leaching of released nutrients to lower horizons. This could be aided by nutrient removal in crop parts during harvest, without adequate soil nutrient replenishment. Under the woodland ecosystem, litter-fall may help to maintain steady-state infiltration rate (range: $45-126 \mathrm{~cm} \mathrm{~h}^{-1}$ in clay; $32-97 \mathrm{~cm} \mathrm{~h}^{-1}$ in loamy sand) by protecting the soil surface from damage and ensuring the formation of stable aggregates which preserve pore continuity. It was recommended that when miombo woodlands are to be cleared, management decisions that reduce tillage intensity and maximize residue retention should be put into practice; otherwise the clearing is strongly discouraged.
\end{abstract}

(c) 2013 Elsevier B.V. All rights reserved.

\section{Introduction}

Miombo woodlands are an essential biome that supports a large number of fauna and flora and covers about $10 \%$ of the African land area that is equivalent to about 2.5-4 million $\mathrm{km}^{2}$ (Goldberg, 2001; Nord, 2008). In most cases, and particularly in Zimbabwe, the woodlands are found on infertile soils in warm areas with a mean annual temperature of $18-23^{\circ} \mathrm{C}$ (Campbell et al., 1996; Lulandala, 2007) and a relatively low mean rainfall amount of $600-800 \mathrm{~mm}$ (Goldberg, 2001). The soils are therefore relatively fragile in terms of susceptibility to degradation and would require careful management since reclamation of degraded soils is generally

\footnotetext{
* Corresponding author. Tel.: +263 4 704543; fax: +263 4704543

E-mail address: faraimaps@yahoo.com (F. Mapanda).
}

expensive and sometimes not fully achievable. These soils usually have low cation exchange capacity (CEC) and low contents of $\mathrm{N}$ and extractable $\mathrm{P}$ (Frost, 1996), making them unsuitable for permanent agriculture and requiring considerable vegetation cover to avoid erosion and degradation (Campbell et al., 2007). However, in practice, the woodlands have experienced massive deforestation (WWF, 2010) and clearing for crop production (FAO, 2010). It is critical to understand the effects of such land use change on soil properties and land degradation in order to provide evidencebased policy advice on land management.

Miombo tree communities are dominated by generas Brachystegia, Julbernardia and Isoberlina (Fabaceae, subfamily Caesalpinioideae) that are found in most countries of southern and central Africa, and being the dominant forest component of Angola, Zambia, Tanzania, Malawi, Mozambique and Zimbabwe (Malmer, 2007). The canopy coverage determines the density and height of 
the grass layer, and common canopy coverage is $50 \%$, which enables grass to grow even up to $2 \mathrm{~m}$ in height (Nord, 2008). The miombo woodlands and their accumulation of leaf litter on soil surfaces have been shown to foster higher levels of organic matter in the surface soil, promoting better soil structure, improving soil fertility, and carbon storage in both soil and woody biomass (Walker and Desanker, 2004; Munishi et al., 2010; Timberlake and Chidumayo, 2011). A negative change in these physico-chemical properties may result in severe land degradation. The permanent vegetation therefore plays an important role in improving soil properties and processes that ensures a healthy ecosystem.

Globally, there are concerns about changes in land use and land cover due to the realization that land surface processes influence climate and these processes impact on ecosystem goods and services (Lambin et al., 2003). Sileshi et al. (2007) summarized the ecosystem services in the miombo eco-region of eastern and southern Africa into: provisioning services, such as food and energy; regulatory services, including climate and microclimate modification; and supporting services, such as biodiversity conservation and pollination in the miombo eco-region. Deforestation and conversion of the woodlands to agricultural land may affect climate processes in many ways related to their impact of reduced flora (Katsvanga et al., 2005) and fauna (Sileshi and Mafongoya, 2006). Mapanda et al. (2010) studied the effects of land cover and land use on soil emission of $\mathrm{CO}_{2}, \mathrm{CH}_{4}$ and $\mathrm{N}_{2} \mathrm{O}$ across different ecosystems that included undisturbed, cleared and cultivated miombo woodlands in Zimbabwe. They indicated that land cover change was an important driver of greenhouse gas emissions. Their study also pointed to the need to look into how soil physical, chemical and biological properties have changed with the clearing and cultivation of miombo woodlands since these properties would normally influence microbial activities that result in greenhouse gas emissions.

The objective of this study was to determine the effect of disturbing miombo woodlands by clearing and cultivation on selected soil chemical, physical and biological properties of two contrasting soils in central Zimbabwe. Literature on converting miombo woodlands to agricultural land in developing countries has pointed to a number of causes that include high population in relation to available land, high dependency on non-oil primary products, and market and policy failures (Chipika and Kowero, 2000; Barbier, 2004). It was hypothesized that these conversions would result in deterioration of soil chemical, physical and biological properties, thus impacting negatively on ecosystem health. This was based on the assumption that when a soil is cultivated, it often loses $20-40 \%$ of its carbon (C) and the largest part of this loss occurs within the first 5 years (Davidson and Ackerman, 1993; Williams et al., 2008).

\section{Materials and methods}

\subsection{Study sites}

The study was conducted at the University of Zimbabwe Farm (UZ-Farm) located about $15 \mathrm{~km}$ north of Harare $\left(31^{\circ} 00^{\prime} 48^{\prime \prime} \mathrm{E}\right.$; $17^{\circ} 42^{\prime} 24^{\prime \prime} \mathrm{S}$ ), and the Grasslands Research Station (GR-Station) located about $67 \mathrm{~km}$ east of Harare $\left(31^{\circ} 29^{\prime} 00^{\prime \prime} \mathrm{E} ; 18^{\circ} 10^{\prime} 14^{\prime \prime} \mathrm{S}\right)$. The two experimental sites were the same sites on which a four-season (2006/2007-2009/2010) greenhouse gas emissions study, partly reported by Mapanda et al. (2010) and also Mapanda et al. (2012), was done. A soil and vegetation study had been carried out before selection of areas with uniform vegetation and similar soil type at each site. The woodland area at the UZ-Farm was about 100 ha and mostly occupied by mixed Brachystegia spiciformis and Julbernardia globiflora tree species, while the woodland at the GR-Station covered about 2200 ha with similar tree species, in addition to
Table 1

General characteristics of the study sites including climatic data covering the period 2005-2010, soil properties (mean \pm standard deviation) in the $0-0.1 \mathrm{~m}$ depth and vegetation status of woodlands in 2006 (Mapanda et al., 2010).

\begin{tabular}{|c|c|c|}
\hline Characteristic & UZ-Farm & GR-Station \\
\hline Altitude (m above sea level) & 1505 & 1637 \\
\hline Mean annual rainfall $\left(\mathrm{mm} \mathrm{yr}^{-1}\right)$ & $748 \pm 176$ & $829 \pm 79$ \\
\hline Mean maximum temperature $\left({ }^{\circ} \mathrm{C}\right)$ & $26.1 \pm 0.7$ & $24.4 \pm 0.3$ \\
\hline Mean minimum temperature $\left({ }^{\circ} \mathrm{C}\right)$ & $12.4 \pm 0.4$ & $10.5 \pm 0.2$ \\
\hline Soil parent material & Dolerite & Granite \\
\hline Slope $(\%)$ & $2-3$ & $<2$ \\
\hline Soil pH (in water) & $5.8 \pm 0.6$ & $5.2 \pm 0.7$ \\
\hline Bulk density $\left(\mathrm{Mg} \mathrm{m}^{-3}\right)$ & $1.49 \pm 0.04$ & $1.81 \pm 0.06$ \\
\hline Soil organic C (\%) & $1.66 \pm 0.55$ & $0.95 \pm 0.06$ \\
\hline Clay content $(\%)$ & $51 \pm 0$ & $11 \pm 0.7$ \\
\hline Cation exchange capacity $\left(\mathrm{cmol}_{\mathrm{c}} \mathrm{kg}^{-1}\right)$ & $9.5 \pm 1.5$ & $4.2 \pm 0.1$ \\
\hline Tree density $\left(\mathrm{ha}^{-1}\right)$ & $2604 \pm 429$ & $4896 \pm 729$ \\
\hline${ }^{\text {a }}$ Shrub density $\left(\mathrm{ha}^{-1}\right)$ & $2500 \pm 977$ & $3854 \pm 1310$ \\
\hline${ }^{\mathrm{b}} \mathrm{DBH}$ range (and median) (m) & $0.05-0.27(0.10)$ & $0.04-0.15(0.08)$ \\
\hline
\end{tabular}

${ }^{a}$ shrub is woody vegetation with height of $<2 \mathrm{~m}$.

${ }^{\mathrm{b}} \mathrm{DBH}$ is tree diameter at breast height.

Terminalia sericea and Burkea africana, in association with Combretum and Acacia species in other areas. The Hyparrhenia species were the most dominant grass species co-existing with the trees at both sites. The red clay soil at UZ-Farm is classified as Chromic luvisol (FAO, 1988) derived from dolerite, while the brown loamy-sand at GR-Station is a Ferric acrisol (FAO, 1988) derived from granite (Nyamapfene, 1991). Other soil and site characteristics are given in Table 1.

\subsection{Experimental treatment and management}

The treatments were first introduced at the two experimental sites in October 2006 as described by Mapanda et al. (2012). Four treatments were introduced, each on a plot measuring $4 \mathrm{~m} \times 6 \mathrm{~m}$ arranged in a randomized complete block design with four replicates. The plot sizes were a fair compromise to minimize excessive clearing of the woodlands, and they were generally within the range recommended by Walker et al. (2012) as a reasonable balance of effort and precision for the tree sizes found at the two sites (Table 1). At such plot sizes variability in soil and vegetation properties was also minimum before clearing. The treatments were: (1) undisturbed woodland, (2) cleared woodland, without cultivation and fertilization, (3) cleared woodland with cultivation, and without $\mathrm{N}$-fertilization (maize-cropped), and (4) cleared woodland with cultivation, with fertilization (maizecropped, $120 \mathrm{~kg} \mathrm{~N} \mathrm{ha}^{-1}$ ).

The clearing of tree stands from just above-ground was carried out once in October 2006 (about two weeks before the onset of the cropping season) by hand using axes, and cultivation was undertaken manually and annually using hand picks to achieve a plough depth of about $0.15-0.20 \mathrm{~m}$ in the $2006 / 2007,2007 / 2008$, $2008 / 2009$ and 2009/2010 cropping seasons. Maize (Zea mays L.) was sown each season, and $\mathrm{NH}_{4} \mathrm{NO}_{3}(34.5 \% \mathrm{~N})$ was applied annually at a rate of $120 \mathrm{~kg} \mathrm{~N} \mathrm{ha}^{-1}$ (for treatment 4), while annual basal dressings of $\mathrm{P}$ ( $30 \mathrm{~kg} \mathrm{ha}^{-1}$, as single super phosphate) and $\mathrm{K}$ ( $30 \mathrm{~kg} \mathrm{ha}^{-1}$, as muriate of potash) were applied before sowing on all plots under maize, including those that did not receive $\mathrm{N}$ fertiliser (i.e. treatment 3).

\subsection{Soil sampling and preparation of samples}

Soil sampling for determination of soil physical, chemical and biological properties in the experimental plots was conducted once during the fifth season (2010/2011) in which no cropping was done. The sampling was done in mid-January when the soil was relatively moist and friable. Mini-pits were dug to a depth of up to $25 \mathrm{~cm}$ at 
three randomly selected locations in each plot using a shovel. The mini-pits enabled visual inspection of the strata, allowed more accurate measurement of soil depths and reduced soil disturbance by retaining the structural integrity of the soil. Soil samples were collected from one wall of each pit at three depths $(0-5 \mathrm{~cm}, 6-10 \mathrm{~cm}$, and $11-20 \mathrm{~cm})$, starting with the bottom depth to avoid cross contamination. Each collected sample was placed in a labelled plastic bag and the samples were taken to the laboratory where each sample was thoroughly mixed and allowed to air dry. Part of the soil to be used for the determination of aggregate stability, nutrients $(\mathrm{N}$, $\mathrm{P}$ and $\mathrm{K}$ ) and cation exchange capacity was sieved through a $2 \mathrm{~mm}$ sieve, while the remaining soil was ground to pass through a $0.5 \mathrm{~mm}$ sieve for determination of soil organic $\mathrm{C}$, and microbial biomass $\mathrm{C}$ and $\mathrm{N}$. The prepared soil samples were stored in clearly labelled khaki bags at room temperature, while the soil fraction for microbial biomass $\mathrm{C}$ and $\mathrm{N}$ were stored in a refrigerator at $4{ }^{\circ} \mathrm{C}$.

\subsection{Analysis of soil samples for chemical properties}

Soil samples were analyzed for soil organic C, nutrients (total N, $\mathrm{P}$ and $\mathrm{K}$ ) and cation exchange capacity using the methods described by Okalebo et al. (2002). Soil organic $C$ was extracted using concentrated $\mathrm{H}_{2} \mathrm{SO}_{4}$ and $\mathrm{K}_{2} \mathrm{Cr}_{2} \mathrm{O}_{7}$ with external heating, and determined by titrating with $\mathrm{Fe}\left(\mathrm{NH}_{4}\right)_{2}\left(\mathrm{SO}_{4}\right)_{2} \cdot 6 \mathrm{H}_{2} \mathrm{O}$. Nutrients (total $\mathrm{N}, \mathrm{P}$ and $\mathrm{K}$ ) were extracted using concentrated $\mathrm{H}_{2} \mathrm{SO}_{4}$ and $\mathrm{H}_{2} \mathrm{O}_{2}$ with external heating. Total $\mathrm{N}$ was determined using the semi-micro Kjeldahl method (Bremner and Mulvaney, 1982), while total P was determined colorimetrically using the UV visible spectrophotometer after generating colour using ascorbic acid. Total $\mathrm{K}$ was determined using the atomic emission spectrophotometer. Cation exchange capacity and the exchangeable bases were determined by extraction using ammonium acetate as described by Anderson and Ingram (1993). Exchangeable K and Na were measured by flame photometry, and Ca and Mg by atomic absorption spectrophotometry.

\subsection{Analysis of soils for infiltration rate and aggregate stability}

Steady-state infiltration rate was measured in situ using the double ring infiltrometer as described by Anderson and Ingrams (1993). Metal rings (inner ring, $32 \mathrm{~cm}$ diameter, outer ring $54 \mathrm{~cm}$ diameter, height $40 \mathrm{~cm}$ ) were driven vertically into the soil in each plot for about $15 \mathrm{~cm}$ using a hammer with the smaller ring centred in the larger ring. The soil surface was not cleaned i.e. was maintained in its natural state while the double ring was driven into the soil. Both cylinders were filled with water to a height of $14 \mathrm{~cm}$. The time taken for the head in the inner ring to fall by one centimetre was recorded allowing the head to fall to $4 \mathrm{~cm}$. When the head fell to $4 \mathrm{~cm}$ it was refilled to $14 \mathrm{~cm}$ continuing to note the time taken for the head to fall by $1 \mathrm{~cm}$. The water level in the inner and outer ring was always maintained at the same height. When the time taken for the water level to fall was constant the soil steady state infiltration was assumed to have been achieved and the experiment stopped. The results were fitted to the Kostiakov equation (Hillel, 1982) shown in Eq. (1).

$F=a t^{-b}$

where $F$ is the infiltration rate in $\mathrm{cm} \mathrm{h}^{-1} ; t$ is the time from start to end of the experiment in hours; $a$ is the constant representing the cumulative infiltration after time $\mathrm{t}$ of infiltration, and $b$ is the constant that gives the relative importance of time of infiltration.

Water stable aggregates were measured on soil samples using the Yoder apparatus adapted from Kemper and Rosenau (1986). Four grams of air dried soil were passed through a $2 \mathrm{~mm}$ sieve and placed on $0.2 \mathrm{~mm}$ sieves. The sieves were immersed in deionised for $30 \mathrm{~min}$. After $30 \mathrm{~min}$ the sieves were removed and placed on the holders of the wet sieving machine (Yoder apparatus) and the machine was switched on, lowering and raising the nest of sieves through a distance of $1.3 \mathrm{~cm}$ at a rate of 35 cycles per minute for six minutes, following Barthes and Roose (2002). After six minutes the machine was switched off and the soil aggregates on the $0.2 \mathrm{~mm}$ sieve were washed into pre-weighed containers and oven dried at $105{ }^{\circ} \mathrm{C}$ for $24 \mathrm{~h}$. After oven drying containers with soil the aggregates were reweighed to determine the weight of the aggregates and the container. After weighing the soil, aggregates were sieved, using $0.2 \mathrm{~mm}$ sieves, into dispersive $0.05 \mathrm{M} \mathrm{NaOH}$ solution for $30 \mathrm{~min}$ using the same Yoder apparatus, washed into pre-weighed containers oven dried at $105^{\circ} \mathrm{C}$ for $24 \mathrm{~h}$ and weighed to determine the weight of coarse sand ( $C S>0.2 \mathrm{~mm}$ ). The results were expressed as Macro-aggregate index (Ima) defined by Eq. (2), i.e. 1000 -fold the weight ratio of water-stable macro-aggregates to oven-dried initial sample minus coarse sands:

$\operatorname{Ima}=\frac{1000(F>0.2-\mathrm{CS})}{\mathrm{gDM}-\mathrm{CS}}$

where: $\mathrm{DM}=$ dry matter content of the sample; $\mathrm{CS}=$ coarse sand $(>0.2 \mathrm{~mm}) ; g=$ mass of sample used, and $F>0.2=$ fraction of soil on $0.2 \mathrm{~mm}$ sieve after sieving.

\subsection{Analysis of soil samples for microbial biomass $C$ and $N$}

Soil microbial biomass $\mathrm{C}$ and $\mathrm{N}$ were determined as the difference in extractable $\mathrm{C}$ and $\mathrm{N}$ between the fumigated and unfumigated soil (Eqs. (3) and (4)). The chloroform fumigation extraction method adapted from Howarth and Paul (1994) was used to release microbial cell material from microbial biomass. In this method, $50 \mathrm{ml}$ beaker containing $5 \mathrm{~g}$ fresh soil samples and a $100 \mathrm{ml}$ beaker with $50 \mathrm{ml}$ alcohol-free chloroform were placed in vacuum desiccators. Another desiccator was maintained without chloroform and was kept under dark conditions for $72 \mathrm{~h}$ at room temperature. The fumigated desiccators were then evacuated using a vacuum pump until the chloroform rapidly boiled. Soil samples were transferred to $250 \mathrm{ml}$ conical flask and the fumigated and unfumigated soils were analyzed for extracted $C$ using the Walkley-Black method (Nelson and Sommers, 1996), and extractable $\mathrm{N}$ using the semi-micro Kjeldal method (Bremner and Mulvaney, 1982; Okalebo et al., 2002).

Vance et al. (1987):

Microbial $C=\left(\mathrm{EC}_{f}-\mathrm{EC}_{u}\right) \times 2.64$

Brookes et al. (1985):

Microbial $\mathrm{N}=\frac{\mathrm{EN}_{f}-\mathrm{EN}_{u}}{0.54}$

where: $\mathrm{EC}_{f}$ and $\mathrm{EC}_{u}=$ extractable $\mathrm{C}$ of fumigated and unfumigated soils, respectively; $\mathrm{EN}_{f}$ and $\mathrm{EN}_{u}=$ extractable $\mathrm{N}$ of fumigated and unfumigated soils, respectively.

According to Howarth and Paul (1994), the fumigation extraction method poses no risk of $\mathrm{NH}_{4}{ }^{+}$immobilization and denitrification activity, and there is low interference from nonmicrobial labile $\mathrm{C}$ and $\mathrm{N}$ substrates that can be used during incubation as in other methods.

\subsection{Data analysis}

Data sets of measured soil chemical, physical and biological properties were subjected to two way analysis of variance using GenStat 8.1 statistical package to analyze differences between treatments, while the least significant difference (LSD) at $P=0.05$ was used in separation of significantly different treatments. Linear 
regression analysis was done to establish if there was any relationship between soil organic $\mathrm{C}$, aggregate stability and steady-state infiltration rate.

\section{Results}

\subsection{Soil chemical properties}

Soil organic C ranged from 0.69 to $2.24 \%$ in the UZ-Farm clay soil and from 0.24 to $1.43 \%$ in the GR-Station loamy sand soil (Fig. 1). Compared with the undisturbed woodland the cultivation of cleared woodland significantly $(P<0.05)$ reduced soil organic $C$ at all depths by $16-55 \%$ (mean $36 \%$ ) in the clay soil and $23-73 \%$ (mean $50 \%$ ) in the loamy sand soil. This change was more distinct on plots that were cultivated for four cropping seasons without $\mathrm{N}$ fertiliser application. On the contrary, the plots that were cleared once in the $2006 / 2007$ cropping season had the highest soil organic C within the first two depths in the clay soil after four seasons. The general observation on these plots was that of a more vigorous growth of numerous suckers from the tree-stumps compared with the undisturbed woodland plots. By the fourth season it was mainly one or two suckers that were dominating and growing taller than the others. A similar trend was observed on the loamy sand soil but the vegetation proliferation was less than that observed on the clay soil. In the loamy sand, there was however, no considerable change in soil organic $C$ due to clearing, except at the $6-10 \mathrm{~cm}$ depth that showed a $36 \%$ decline in soil organic $C$ relative to the undisturbed woodland plots.

The total concentrations of the major plant nutrients, N, P and K, in the woodland and cropped plots after four cropping seasons are shown in Fig. 2. The overall trend in total N (0.07-0.23\% in the UZFarm clay soils; $0.05-0.19 \%$ in the GR-station loamy sand soils) was that of a decline in total $\mathrm{N}$ for cleared plots and plots that were cleared and cultivated without $\mathrm{N}$ application, especially at the lowest depth of $11-20 \mathrm{~cm}$ (Fig. 2a and b). The application of $\mathrm{NH}_{4} \mathrm{NO}_{3}$ resulted in a decline in total $\mathrm{N}$ in the clay soil compared to no $\mathrm{N}$ application, except in the $6-10 \mathrm{~cm}$ depth. This $6-10 \mathrm{~cm}$ depth corresponded with the depth of fertiliser incorporation at planting, and also resulted in the buildup of soil $\mathrm{N}$ in the loamy sand soil (Fig. 2b). Total $P$ ranged from 0.02 to $0.16 \%$ in UZ-Farm clay soils and from 0.02 to $0.08 \%$ in the GR-Station loamy sand soils, and significant treatment effects $(P<0.05)$ were noted in both soils and at all depths. The least $P$ concentration in clay soil was found in cleared woodland plots while the undisturbed woodland plots had the highest $P$ concentrations in the $0-5 \mathrm{~cm}$ and $6-10 \mathrm{~cm}$ depths (Fig. 2c). In the loamy sand soils, there was no distinct trend across the sampled depths but the highest $P$ concentrations were found among the cultivated plots on which $30 \mathrm{~kg} \mathrm{P} \mathrm{ha}^{-1}$ season $^{-1}$ were applied (Fig. 2d). Total K ranged from 0.41 to $1.09 \%$ in the UZ-Farm clay soils and from 0.25 to $1.30 \%$ in the GR-Station loamy sand soils (Fig. 2e and $\mathrm{f}$ ). No distinct trend could be established in $\mathrm{K}$ concentration with treatment or soil depth in the clay soil. However, in the loamy sand soil cropped plots had the least $\mathrm{K}$ concentrations of not more than $0.52 \%$ in all soil depths, despite having received $30 \mathrm{~kg} \mathrm{~K} \mathrm{ha}^{-1}$ season $^{-1}$ for four cropping seasons.

The total exchangeable bases (TEB) were 7.4-20.1 $\mathrm{cmol}_{\mathrm{c}} \mathrm{kg}^{-1}$ at the UZ-Farm, and 7.0-15.5 $\mathrm{cmol}_{\mathrm{c}} \mathrm{kg}^{-1}$ at the GR-Station, while the cation exchange capacities (CECs) were $9.6-21.0 \mathrm{cmol}_{\mathrm{c}} \mathrm{kg}^{-1}$ at the UZ-Farm, and 9.3-18.7 $\mathrm{cmol}_{\mathrm{c}} \mathrm{kg}^{-1}$ at the GR-Station (Fig. 3). The clearing and cultivation of woodlands significantly $(P<0.05)$ reduced both total exchangeable bases and cation exchange capacity. The cation exchange capacity decreased at all depths by $15-54 \%$ (mean $38 \%$ ) in the clay soil and $14-50 \%$ (mean $32 \%$ ) in the loamy sand soil. These rates of decline in cation exchange capacity closely correspond to the rate of soil organic $\mathrm{C}$ decline in the clay soil, but were relatively less responsive to the rate of soil organic $\mathrm{C}$ decline in the loamy sand soil.

\subsection{Steady-state infiltration rate and aggregate stability}

Converting the miombo woodlands to croplands significantly $(P<0.05)$ reduced the steady-state infiltration rate of both the UZFarm clay soil and the GR-Station loamy sand soil, after four cropping seasons (Fig. 4$)$. The steady state infiltration rates $\left(F_{\text {final }}\right)$ ranged from 45 to $126 \mathrm{~cm} \mathrm{~h}^{-1}$ in the UZ-Farm clay soil and from 32 to $97 \mathrm{~cm} \mathrm{~h}^{-1}$ in the GR-Station loamy sand. While the clearing of trees alone did not show any considerable effect on the $F_{\text {final }}$ in the loamy sand soil relative to the undisturbed woodland (Fig. 4b), it resulted in a $33 \%$ decline in the $F_{\text {final }}$ in clay soil. Clearing and cultivation of plots resulted in 57-80\% decline in the $\mathrm{F}_{\text {final }}$ on both soils, and the highest decline was observed on cropped plots that did not receive $\mathrm{N}$ fertiliser at the UZ-Farm clay soil. The effect of $\mathrm{N}$ fertiliser application on the $\mathrm{F}_{\text {final }}$, relative to none application, was however insignificant on the GR-Station loamy sand soil.

The water-stable macro-aggregation indices (Ima) ranged from 565 to 913 (mean 784) at the UZ-Farm and from 373-874 (mean 690 ) at the GR-Station (Fig. 5). There was a positive correlation $(P<0.05)$ between aggregate stability and infiltration rate on both clay soil $(r=0.5)$ and loamy sand soil $(r=0.6)$. Aggregate stability significantly decreased, by $9-38 \%$, with both clearing and cropping without $\mathrm{N}$ fertiliser application in the three sampled depths at the UZ-Farm. At this site, cropped plots with $\mathrm{N}$ fertiliser application had macroaggregation indices of similar magnitudes to those on the undisturbed woodlands, except at the $0-5 \mathrm{~cm}$ depth in which
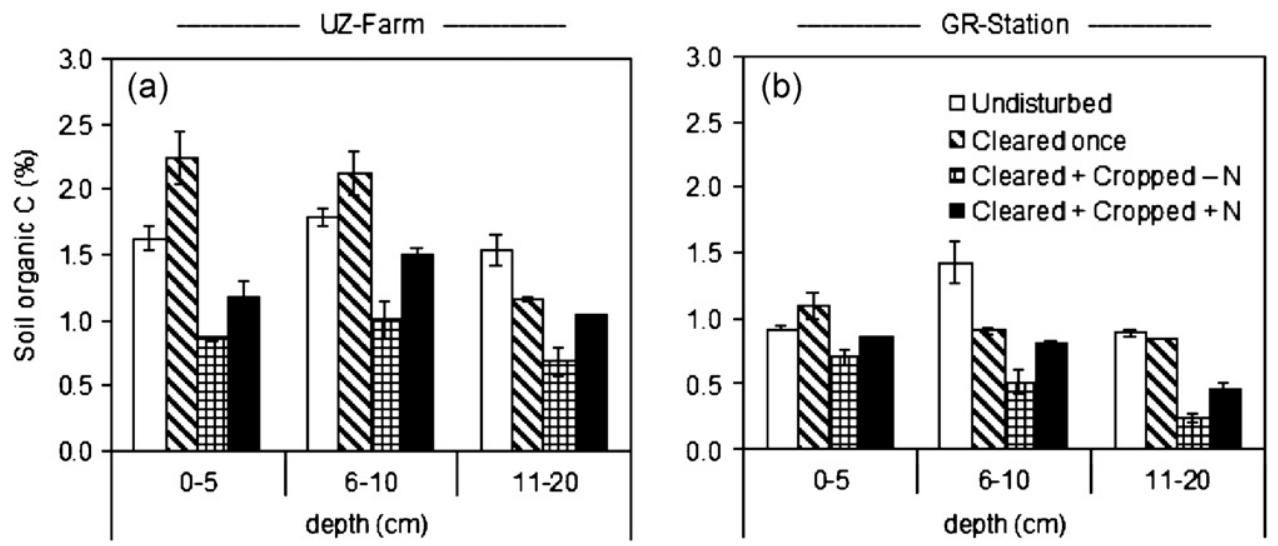

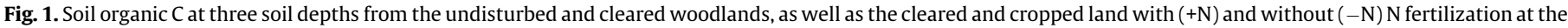
UZ-Farm (a) and GR-Station (b). Error bars denote standard errors of means. 

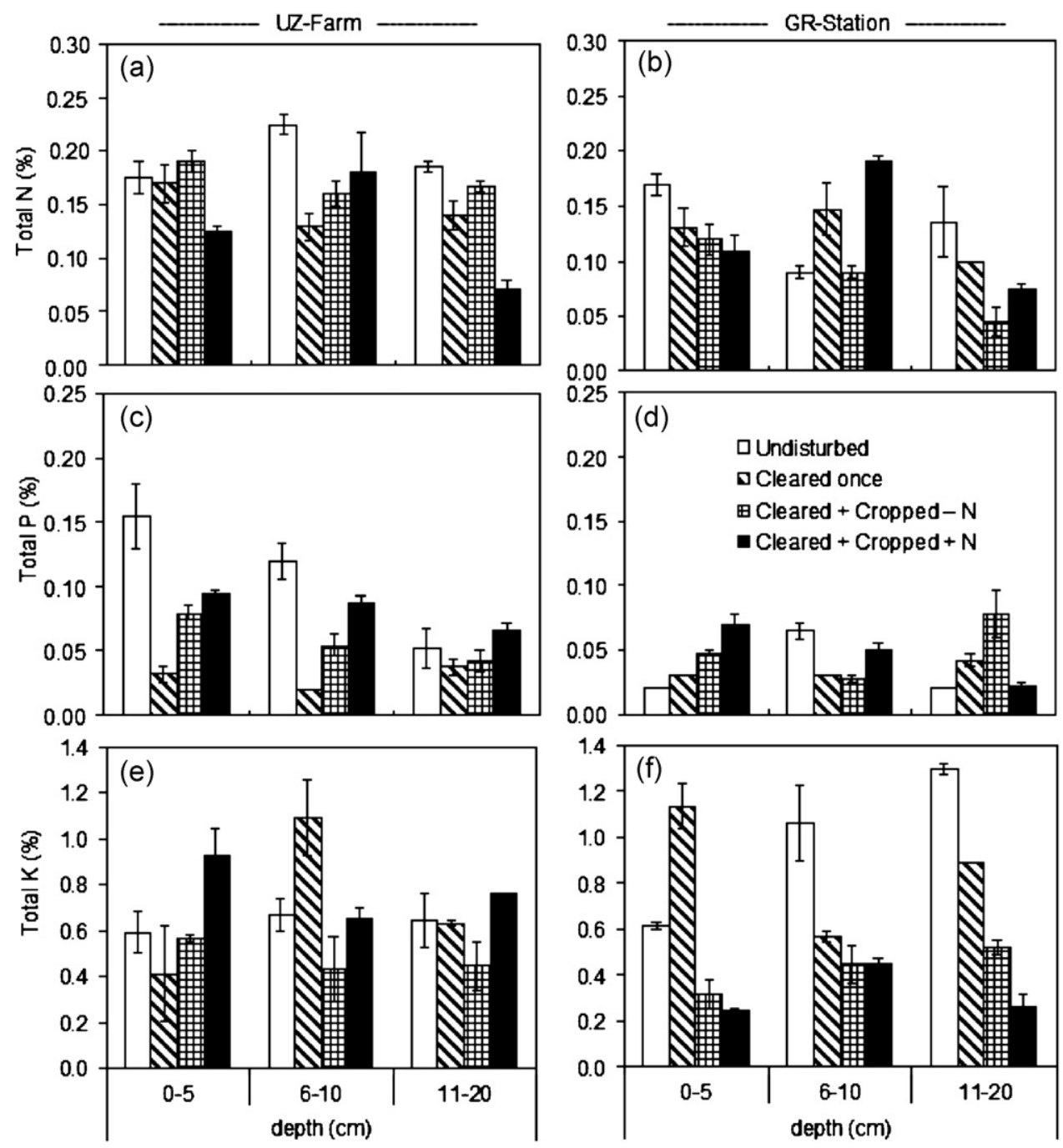

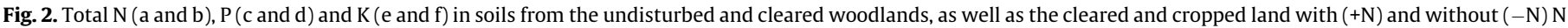
fertilization at the UZ-Farm and GR-Station at three depths. Error bars denote standard errors of means.

the index decreased by $17 \%$. On the contrary, the highest aggregate stability in the GR-Station loamy sand soil was found on plots that were cleared once, without cultivation (Fig. 5b), and this is the same treatment that did not show significant response on infiltration rate (Fig. 4b). Cropped plots without $\mathrm{N}$ fertiliser application had the highest decline in aggregate stability (change of $27-51 \%$ ) relative to the undisturbed woodland plots in all sampled depths at the GR-Station. There was a positive correlation $(P<0.05)$ between aggregate stability and soil organic $C$ on both clay soil $(r=0.61)$ and loamy sand soil $(r=0.51)$.

\subsection{Soil microbial biomass $C$ and $N$}

Soil microbial C $(0.06-0.54 \%$ at the UZ-Farm; $0.02-0.37 \%$ at the GR-Station) and microbial N (0.02-0.06\% at the UZ-Farm; 0.02$0.05 \%$ at the GR-Station) differed significantly $(P<0.05)$ across treatments, and this was largely consistent at all the soil depths (Fig. 6). The undisturbed woodland plots had highest soil microbial $\mathrm{C}$ and $\mathrm{N}$ than the cleared or the cleared and cropped plots. Soil microbial $C$ decreased by $50-89 \%$ in the clay soils and by $38-92 \%$ in the loamy sand soil after four cropping seasons following the clearing and cultivation of the woodlands. However, soil microbial $\mathrm{N}$ decreased by a lesser magnitude (17-67\% in the clay soil; $0-50 \%$ in the loamy sand soil) following the same woodland disturbances.

\section{Discussion}

The hypothesis that the clearing of woodlands and maizecropping would result in deterioration of soil chemical, physical and biological properties relative to the undisturbed woodlands was supported. However, the extent and nature of change in soil quality was variable and depended on the soil type and sampling depth of the soil. Results showed that the clearing of trees without cultivation does not always translate to a decline in soil organic C after four seasons, unless the clearing is followed by successive cultivation and cropping, and worse cropping without N fertilization. The indication by Davidson and Ackerman (1993) and Williams et al. (2008), that when the soil is cultivated, it often loses $20-40 \%$ of its organic C mostly within the first 5 years was also supported by the results of this study (Fig. 1). Munishi et al. (2010) investigated the role of miombo woodlands as C sinks in Tanzania, and noted soils as having much potential for $\mathrm{C}$ storage, while the decrease in woodland density due to human utilization contributed to the lowering of $C$ stocks. In this study, a vigorous growth of numerous suckers from the tree-stumps was observed after clearing, and by the fourth season the density of shrubs in cleared plots was relatively higher due to these suckers. This could explain why soil organic $C$ was considerably higher on these plots, which may not be possible when the suckers are removed. 

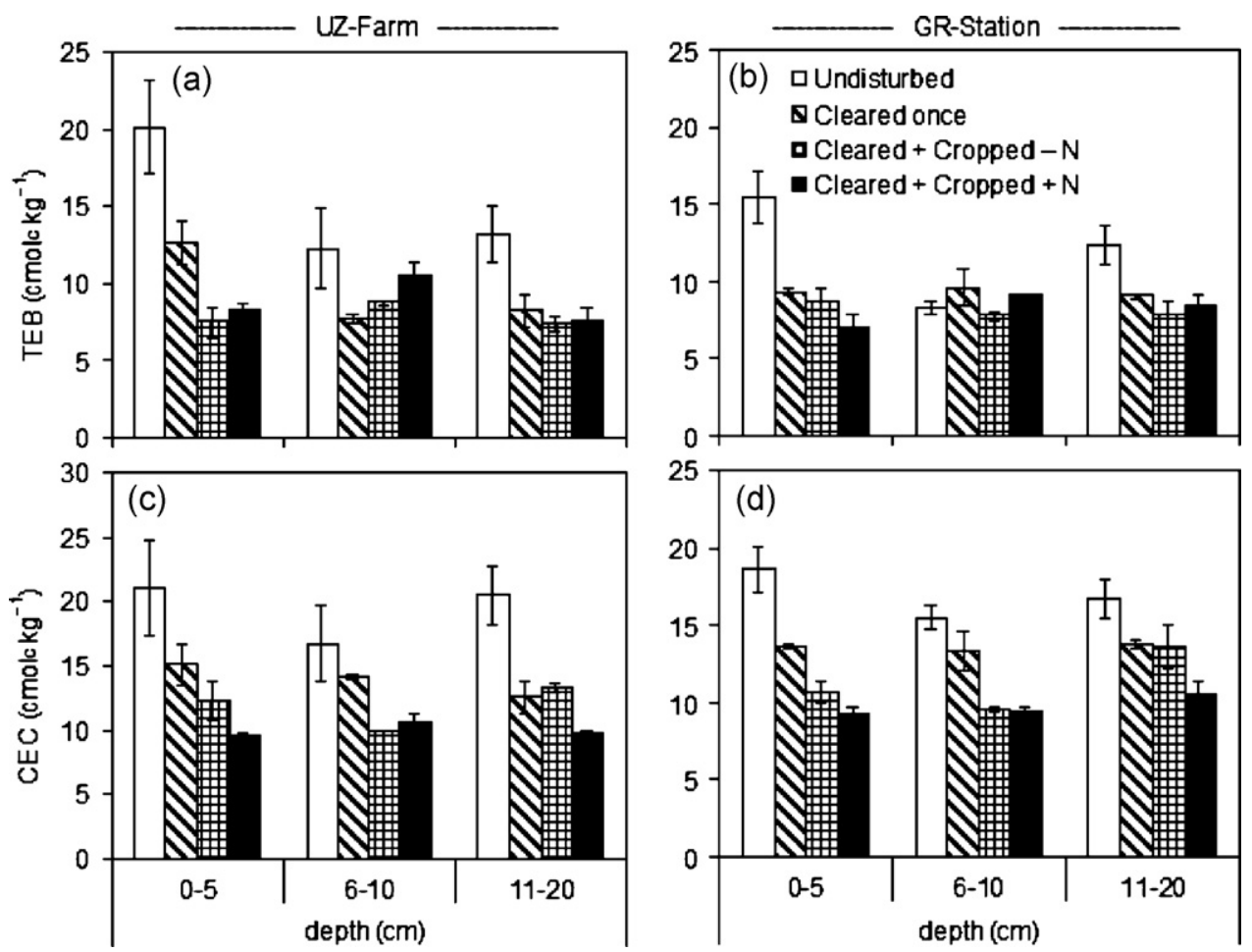

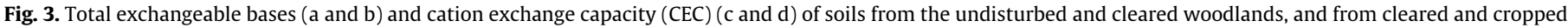
land with $(+\mathrm{N})$ and without $(-\mathrm{N}) \mathrm{N}$ fertilization at the two sites. Error bars denote standard errors of means.

The amounts of total $\mathrm{N}$ and $\mathrm{P}$, and the exchangeable bases overall displayed a downward trend following clearing and also clearing and cultivation (Figs. 2 and 3), and this has been widely observed (Lindo and Visser, 2003; Wick et al., 2005) that after deforestation and land cover change from woodland to cropland, mineralization increases in soil and released nutrients would become more available for microbial transformations and plant uptake, unless they are rapidly lost through leaching (Fukuzawa et al., 2006). According to Baker et al. (2007) the conversion of natural ecosystems to croplands involves other changes that may have far more impact on soil organic $C$ than just mechanical disturbance of the soil that increase aeration. They argued that these changes, including solar radiation on bare fields influence soil temperatures, combined with reduced litter-fall would result

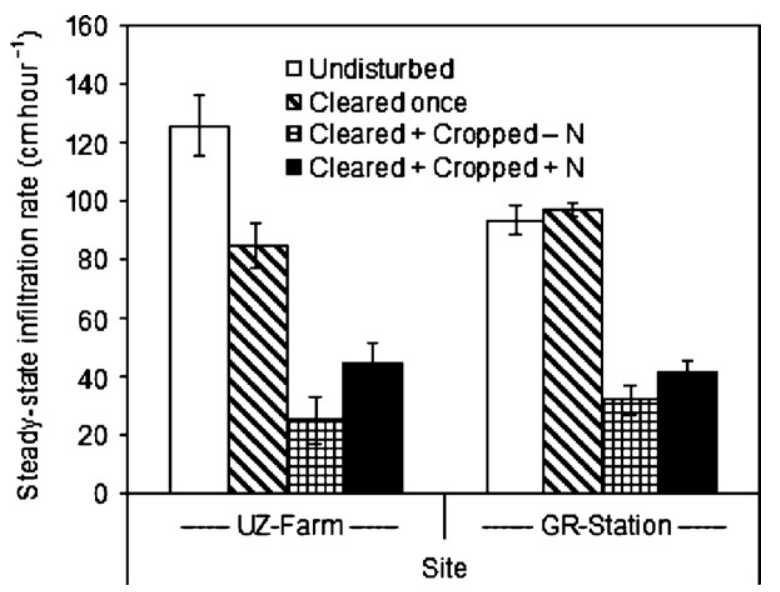

Fig. 4. The rates of water infiltration into the soils from the undisturbed and cleared woodlands, as well as the cleared and cropped land with $(+\mathrm{N})$ and without $(-\mathrm{N}) \mathrm{N}$ fertilization at the UZ-Farm (a) and GR-Station (b). Error bars denote standard errors of means. in reduced soil organic $C$, hence reduced nutrient availability from mineralization. Baker et al. (2007), however lamented the shallow sampling employed in most studies as source of bias, indicating that studies that have involved deeper sampling (beyond the $0.3 \mathrm{~m}$ depths) generally show no $\mathrm{C}$ sequestration advantage from reduced mechanical disturbance of soil.

Results showed a positive concurrence between the change in soil chemical properties (soil organic C, N, P, exchangeable bases and cation exchange capacity), and the change in soil physical properties (infiltration rate and aggregate stability). The macroaggregation indices obtained from the cleared and cultivated plots in this study were relatively higher compared with those obtained from regular crop land in other studies (Barthes and Roose, 2002; Molumeli et al., 2008). The study by Barthes and Roose (2002) gave the indices in the range of 51 to 540 for the $0-10 \mathrm{~cm}$ depth from a range of soil with clay content of $5-45 \%$ under different climatic conditions that included sub-tropical. In their study lower macroaggregation indices considerably favoured higher run-off and soil loss. Infiltration rate decreased with clearance and subsequent cropping of miombo woodlands, and this was in agreement with findings by Nord (2008). The relatively low steady state infiltration rate of GR-Station plots as compared to the UZ Farm could be partly attributed to the higher bulk density of the GR Station plots. The highest infiltration rates in the woodland plots can be attributed to litter layers that maintain macroporosity which increases the infiltration capacity (Van Noordwijk et al., 2003).

Microbial biomass $\mathrm{C}$ and $\mathrm{N}$ decreased significantly with tillage disturbance and lower organic matter inputs after cultivation as reported from other studies (Gosai et al., 2010). The rate of organic $C$ input from plant biomass is considered as the dominant factor controlling the amount of microbial biomass in the soil from both managed ecosystems (Kallenbach and Grandy, 2011) and natural ecosystems (Jin et al., 2010). Research by Mapanda et al. (2010) and Mapanda et al. (2012) on the same site revealed that there was a decrease in soil moisture, and an increase in temperature, on the cultivated plots relative to the undisturbed woodland plots. Singh 


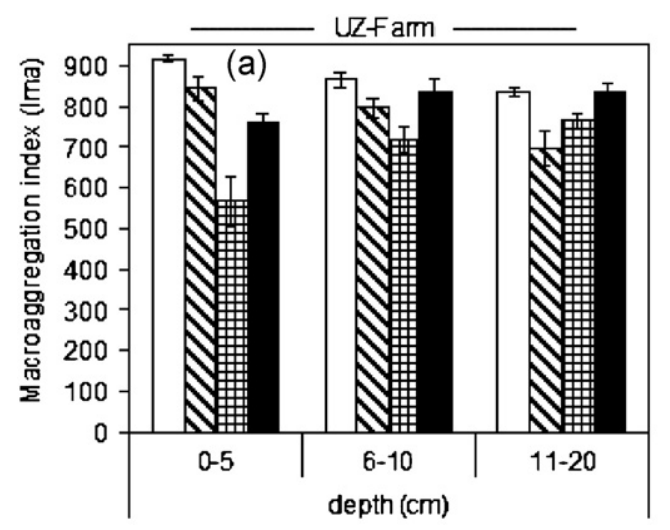

口Undisturbed 田 Cleared + Cropped $-\mathrm{N}$

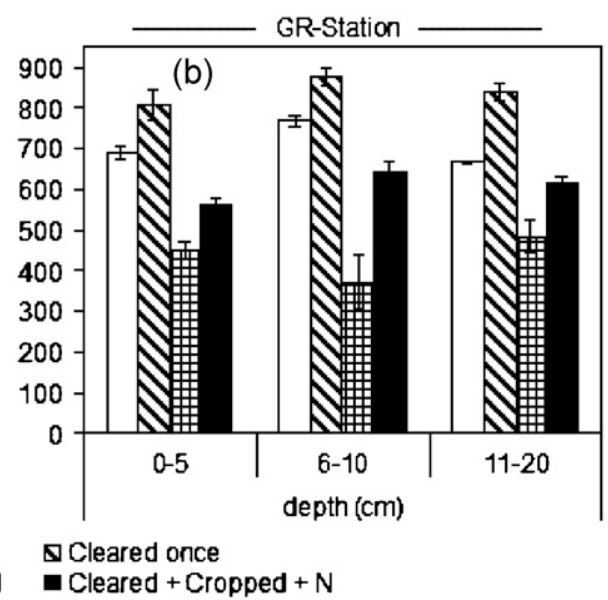

$\Delta$ Cleared once

- Cleared + Cropped $+\mathrm{N}$

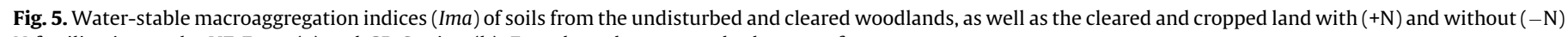
$\mathrm{N}$ fertilization at the UZ-Farm (a) and GR-Station (b). Error bars denote standard errors of means.
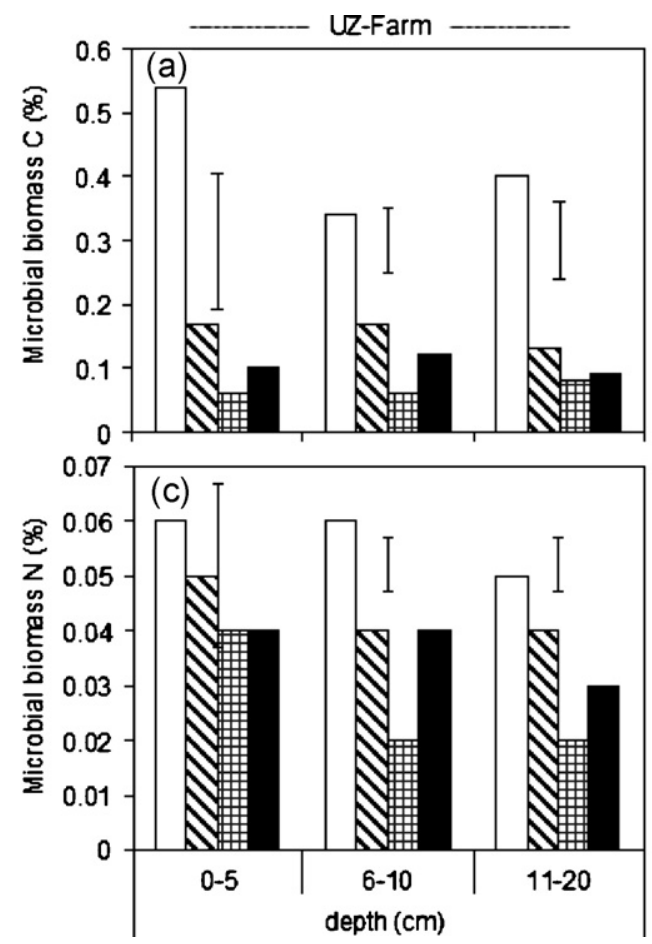
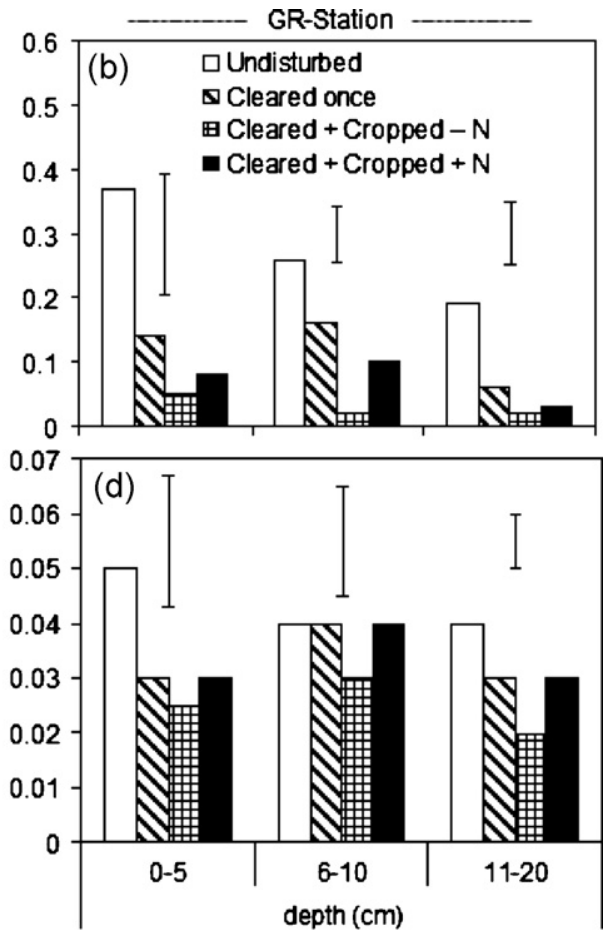

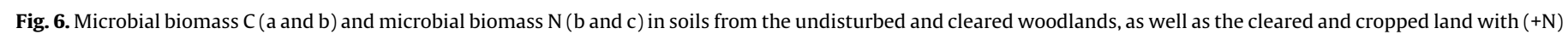
and without $(-\mathrm{N}) \mathrm{N}$ fertilization at the two sites at three depths. Error bars denote least significant difference (lsd).

et al. (2007) reported that soil microbial biomass is affected by soil moisture and soil temperature.

Cultivation reduces fauna and microbial biomass, particularly fungal biomass responsible for the formation of more binding agents, such as extra-cellular polysaccharides, and the development of hyphal networks enmeshing particles and favouring aggregate stability (Six et al., 2006). Continuous tillage and crop production resulted in reduction in water-stable aggregates because aggregates are routinely disrupted by tillage which release physically protected organic C (Roscoe and Buurman, 2003; Zotarelli et al., 2007). The magnitude of reduction in soil microbial biomass $\mathrm{C}$ and $\mathrm{N}$ following disturbances was similar to that found by Gosai et al. (2010), who also indicated that tillage causes significant spatial variation in microbial $\mathrm{C}$ and $\mathrm{N}$ content in the topsoil more than that of the bottom layer. Microbial biomass responds quickly to changes in soil management and is often used as an indicator of soil quality with lower soil microbial biomass $\mathrm{C}$ and $\mathrm{N}$ existing in soils disturbed by cultivation and receiving low organic matter input (Wang et al., 2012).

\section{Conclusion}

Clearing and conversion of miombo woodlands to croplands have considerable implications on soil chemical, physical and biological prosperities, which are site and soil specific in Zimbabwe. The extent and nature of change in soil quality is variable and also depends on the parameter measured and the soil depth considered. Clearing of trees without cultivation does not always translate to a decline in soil organic $C$ after four seasons, unless the clearing is followed by successive cultivation and cropping without $\mathrm{N}$ fertilization. Under the woodland ecosystem litter-fall may help to maintain water infiltration by protecting the soil surface from damage and ensuring the formation of waterstable aggregates which preserve pore continuity. It may be 
recommended that when miombo woodlands are to be cleared, management decisions that reduce tillage intensity should be put into practice, otherwise clearing is strongly discouraged.

\section{Acknowledgements}

This study was sponsored through the grant from the European Union (NitroEurope Project No. 017841). The authors wish to acknowledge assistance from the Chemistry and Soil Research Institute of the Department of Research and Specialist Services, Harare, where some of the analyses were carried out.

\section{References}

Anderson, J.M., Ingram, J.S.I., 1993. Tropical Soil Biology and Fertility: A handbook of Methods. CAB International, Wallingford, UK.

Baker, J.M., Ochsner, T.E., Venterea, R.T., Griffis, T.J., 2007. Tillage and soil carbon sequestration - what do we really know? Agriculture, Ecosystems and Environment 118, 1-5.

Barbier, E.B., 2004. Explaining agricultural land expansion and deforestation in developing countries. American Journal of Agricultural Economics 86, 13471353.

Barthes, B., Roose, E., 2002. Aggregate stability as an indicator of soil susceptibility to runoff and erosion; validation at several levels. Catena 47, 133-149.

Bremner, J.M., Mulvaney, C.S., 1982. Nitrogen-Total. In: Page, A.L., Miller, R.H., Keeney, D.R. (Eds.), Methods of Soil Analysis. Agronomy Monograph 9. second ed. American Society of Agronomy and Soil Science Society of America, Madison, WI, pp. 595-624.

Brookes, P.C., Landman, A.. Pruden, G., Jenkinson, D.S., 1985. Chloroform fumigation and release of soil $\mathrm{N}$ : a rapid direct extraction method to measure microbial biomass $\mathrm{N}$ in soil. Soil Biology and Biochemistry 17, 837-842.

Campbell, B., Frost, P., Byron, N., 1996. Miombo woodlands and their use: overview and key issues. In: Campbell, B. (Ed.), The Miombo in Transition: Woodlands and Welfare in Africa. CIFOR, Bogor, Indonesia, pp. 1-10.

Campbell, B.M., Angelsen, A., Cunningham, A., Katerere, Y., Sitoe, A., Wunder, S., 2007. Miombo woodlands - opportunities and barriers to sustainable forest management. At: http://www.cifor.org/miombo/docs/Campbell_BarriersandOpportunities.pdf (accessed 15.08.12).

Chipika, J.T., Kowero, G., 2000. Deforestation of woodlands in communal areas of Zimbabwe. Is it due to agricultural policies? Agriculture, Ecosystems and Environment 79, 175-185.

Davidson, E.A., Ackerman, I.L., 1993. Changes in soil carbon inventories following cultivation of previously untilled soils. Biogeochemistry 20, 161-193.

FAO, 1988. Soils map of the world: revised legend. Food and Agriculture Organization of the United Nations, Rome.

FAO, 2010. Global forest resources assessment 2010. FAO Forestry Paper 163. Food and Agriculture Organization of the United Nations, Rome.

Frost, P., 1996. The ecology of miombo woodlands. In: Campbell, B. (Ed.), The miombo in transition: woodlands and welfare in Africa. CIFOR, Bogor, Indonesia, pp. 11-58.

Fukuzawa, K., Shibata, H., Takagi, K., Nomura, M., Kurima, N., Fukazawa, T., Satoh, F., Sasa, K., 2006. Effects of clear-cutting on nitrogen leaching and fine root dynamics in a cool-temperate forested watershed in northern Japan. Forest Ecology and Management 225, 257-261.

Goldberg, K., 2001. Southern miombo woodlands. World Wildlife Fund. Washington, DC. At: http://worldwildlife.org/ecoregions/at0719 (accessed 15.01.13).

Gosai, K., Arunachalam, A., Dutta, B.K., 2010. Tillage effects on soil microbial biomass in a rainfed agricultural system of northeast India. Soil and Tillage Research 109, 68-74.

Hillel, D., 1982. Introduction to Soil Physics. Academic Press Inc., New York, USA.

Howarth, W.R., Paul, E.A., 1994. Microbial biomass. In: Weaver, R.W., Angle, S., Bottomley, P., Bexdicet, D., Smith, S., Tabatabai, A., Woollen, A. (Eds.), Methods of Soil Analysis, Part 2: Microbiology and Biochemical Properties. Soil Science Society of America, Madison, WI, pp. 753-773.

Jin, H., Sun, O.J., Liu, J., 2010. Changes in soil microbial biomass and community structure with addition of contrasting types of plant litter in a semiarid grassland ecosystem. Journal of Plant Ecology 3, 209-217.

Kallenbach, C., Grandy, S., 2011. Controls over soil microbial biomass responses to carbon amendments in agricultural systems: a meta-analysis. Agriculture, Ecosystems and Environment 144, 241-252.

Katsvanga, C.A.T., Mukwewa, O., Mupangwa, J.F., Buzuzi, G., 2005. Land use impacts on miombo woodland species in Wenimbi Resettlement Area of Macheke, Zimbabwe. Journal of Sustainable Development in Africa 7, 32-42.

Kemper, W.D., Rosenau, R.C., 1986. Aggregate stability and size distribution. In: Klute, A. (Ed.), Methods of Soil Analysis: Part I: Physical and Mineralogical Methods. Agronomy Monograph 9. second ed. American Society of Agronomy and Soil Science Society of America, Madison, WI, pp. 425-442.

Lambin, E.F., Geist, H.J., Lepers, E., 2003. Dynamics of land-use and land-cover change in tropical regions. Annual Review of Environment and Resources 28, 205-241.

Lindo, Z., Visser, S., 2003. Microbial biomass, nitrogen and phosphorus mineralisation and mesofauna in boreal conifer and deciduous forest floors following partial and clear-cut harvesting. Canadian Journal of Forest Research 33, $1610-$ 1620.

Lulandala, L.L.L., 2007. Principal ecological issues with significance in the management and restoration of Tanzanian miombo woodlands. In: Korpela, L. (Ed.), Management of indigenous tree species for ecosystem restoration and wood production in semi-arid miombo woodlands in eastern Africa. Finnish Forest Research Institute, Finland, pp. 104-108.

Malmer, A., 2007. General ecological features of miombo woodlands and considerations for utilization and management. In: Korpela, L. (Ed.), Management of Indigenous Tree Species For Ecosystem Restoration and Wood Production in Semi-arid Miombo Woodlands in Eastern Africa. Finnish Forest Research Institute, Finland, pp. 34-42.

Mapanda, F., Mupini, J., Wuta, M., Nyamangara, J., Rees, R.M., 2010. A crossecosystem assessment of the effects of land cover and land use on soil emission of selected greenhouse gases and related soil properties in Zimbabwe. European Journal of Soil Science 61, 721-733.

Mapanda, F., Wuta, M., Nyamangara, J., Rees, R.M., Kitzler, B., 2012. Greenhouse gas emissions from savanna (miombo) woodlands: responses to clearing and cropping. African Crop Science Journal 20, 331-346.

Molumeli, P.A., Espinosa Hernandez, V., Ehsan, M., Valdez, S.B., Ojeda Trejo, E., Cetina Alcala, V.M., Alderete-Chavez, A., de la Cruz-Landero, N., Santamaria Delgado, K., 2008. Lupines-invaded pine forest and cultivated scrublands in volcanic ash soils in Mexico: dry-sieved aggregation and instability indices. International Journal of Botany 4, 390-405.

Munishi, P.K.T., Mringi, S., Shirima, D.D., Linda, S.K., 2010. The role of the miombo woodlands of the southern highlands of Tanzania as carbon sinks. Journal of Ecology and the Natural Environment 2, 261-269.

Nelson, D.W., Sommers, L.E., 1996. Total carbon, organic carbon, and organic matter. In: Weaver, R.W., Angle, S., Bottomley, P., Bezdicek, D., Smith, S., Tabatabai, A., Woollen, A. (Eds.), Methods of Soil Analysis: Part 3. Chemical Methods. American Society of Agronomy and Soil Science Society of America, Madison, WI, pp. 961-1010.

Nord, H., 2008. Water infiltration under different land use in miombo woodlands outside Morogoro, Tanzania. M.Sc. Thesis. Department of Forest Ecology and Management, Faculty of Forest Science, Swedish University of Agricultural Sciences, Sweden.

Nyamapfene, K., 1991. Soils of Zimbabwe. Nehanda Publications, Harare, Zimbabwe.

Okalebo, J.R., Gathua, K.W., Woomer, P.L., 2002. Laboratory methods of soil and plant analysis: a working manual. In: Tropical Soil Biology and Fertility Programme, second ed. Soil Society of East Africa Technical Publication No. 1, Marvel EPZ (Kenya) Nairobi.

Roscoe, R., Buurman, P., 2003. Tillage effects on soil organic matter in density fractions of a Cerrado Oxisol. Soil and Tillage Research 70, 107-119.

Sileshi, G., Akinnifesi, F.K., Ajayi, O.C., Chakeredza, S., Kaonga, M., Matakala, P.W., 2007. Contributions of agroforestry to ecosystem services in the miombo ecoregion of eastern and southern Africa African. Journal of Environmental Science and Technology 1, 68-80.

Sileshi, G., Mafongoya, P.L., 2006. Variation in macrofaunal communities under contrasting land use systems in eastern Zambia. Applied Soil Ecology 33, 49-60

Singh, S., Ghoshal, N., Singh, K.P., 2007. Variations in soil microbial biomass and crop roots due to differing resource quality inputs in a tropical dryland agroecosystem. Soil Biology and Biochemistry 39, 76-86.

Six, J., Frey, S.D., Thiet, R.K., Batten, K.M., 2006. Bacterial and fungal contributions to carbon sequestration in agroecosystems. Soil Science Society of America Journal 70, 555-569.

Timberlake, J., Chidumayo, E., 2011. Miombo Ecoregion Vision Report. Occasional Publications in Biodiversity, No. 20. Biodiversity Foundation for Africa, Bulawayo. At: http://www.biodiversityfoundation.org/documents/BFA\%20No.20_Miombo\%20Ecoregion\%20Vision\%20report.pdf (accessed 15.01.13).

Van Noordwijk, M., Farida, A., Verbeist B., Tomich, T.P., 2003. Agroforestry and watershed functions of tropical land use mosaics. ICRAF Southern Asia, Indonesia. At: http://worldagroforestry.org/Sea/Publications/files/paper/PP 0126-05.PDF (accessed 15.01.13)

Vance, E.D., Brookes, P.C., Jenkinson, D.S., 1987. An extraction method for measuring soil microbial biomass C. Soil Biology and Biochemistry 19, 703-707.

Walker, S.M., Desanker, P.V., 2004. The impact of land use on soil carbon in miombo woodlands of Malawi. Forest Ecology and Management 203, 345-360.

Walker, S.M., Pearson, T.R.H., Casarim, F.M., Harris, N., Petrova, S., Grais, A., Swails, E., Netzer, M., Goslee, K.M., Brown, S., 2012. Standard operating procedures for terrestrial carbon measurement: Version 2012. Winrock International, Virginia.

Wang, S. Li, Z., Fan, G., 2012. Soil quality and microbes in organic and conventional farming systems. African Journal of Microbiology Research 6, 5077-5085.

Wick, B., Veldkamp, E., Mello, W.Z., Keller, M., Crill, P., 2005. Nitrous oxide fluxes and nitrogen cycling along a pasture chronosequence in Central Amazonia, Brazil. Biogeosciences 2, 499-535.

Williams, M., Ryan, C.M., Rees, R.M., Sambane, E., Fernando, J., Grace, J., 2008. Carbon sequestration and biodiversity of re-growing miombo woodlands in Mozambique. Global Change Biology 11, 398-420.

WWF., 2010. Environmental impacts of production: deforestation. Agriculture and Environment. World Wide Fund For Nature, Switzerland. At: http://wwf.panda. org/about_our_earth/agriculture_impacts/tobacco/environmental_impacts/ deforestion (accessed 21.08.11).

Zotarelli, L., Alves, B.J.R., Urquiaga, S., Boddey, R.M., Six, J., 2007. Impact of tillage and crop rotation on light fraction and intra-aggregate soil organic matter in two oxisols. Soil and Tillage Research 95, 196-206. 